\title{
ANALISIS FAKTOR INTERNAL DAN EKSTERNAL TERHADAP NON PERFORMANCE FINANCING (NPF) PERBANKAN SYARIAH DI INDONESIA PERIODE TAHUN 2015 - 2018
}

\author{
Kiky Asmara \\ FEB UPN “Veteran” Jawa Timur | kikyasmara25@gmail.com
}

\begin{abstract}
Abstrak: Penelitian berjudul "Analisis Faktor Internal Dan Eksternal Terhadap Non Performance Financing (Npf) Perbankan Syariah Di Indonesia Periode Tahun 2015 - 2018" bertujuan untuk mengetahui faktor-faktor yang mempengaruhi NPF perbankan syariah di Indonesia. Variabel yang digunakan dalam penelitian ini adalah inflasi, kurs,Gross Domestic Product (GDP), Capital Adequacy Ratio ( CAR), Financing Deposi Ratio (FDR) dan BOPO. Data yang digunakan adalah data time series triwulanan periode tahun 2014 sampai tahun 2018 yang bersumber dari Statistik dan Laporan Perkembangan Keuangan Syariah serta dianalisa dengan menggunakan metode regeresi berganda. Hasil penelitian ini menghasilkan kesimpulan bahwa salah satu variabel dalam faktor ekstenal memiliki pengaruh paling besar yaitu variabel BOPO dengan nilai $r 2$ sebesar 0,810 atau sebesar 81 \%sedangakan yang memiliki pengaruh paling kecil adalah variabel GDP dengan nilai r2 sebesar 0,172 atau hanya sebesar $17,2 \%$.
\end{abstract}

Keywords : GDP, CAR, FDR , dan BOPO 


\section{Pendahuluan}

Populasi Muslim di dunia diestimasikan akan mencapai 2 miliar penduduk, yang artinya terdapat potensi yang sangat besar bagi industri keuangan syariah untuk lebih berkembang di masa akan datang. Dari $20 \%$ total populasi tersebut diprediksi akan masuk dalam industri keuangan (bankable Muslim) dan dari $25 \%$ bankable Muslim akan masuk kedalam industri keuangan syariah. Sehingga dapat disimpulkan inklusi keuangan memgang peranan yang sangat penting dalam penhembangan industri keuangan syariah. Apabila jumlah bankable Muslim meningkat menjadi 2 kali lipat maka total asset industri keuangan syariah diperkirakan akan meningkat sebesar ,5 kali lipat atau menjadi US\$5,7 triliun. Sehingga dapat dikatakan Indonesia mempunyai potensi besar menjadi pusat pengembangan industri keuangan syariah.

Beberapa tahun terakhir, keuangan sayriah di Indonesia telah menunjukan perkembangan yang signifikan. Posisi Indonesia pada industri keuangan syariah di pasar global juga meningkat sebagai negara yang diakui di antara negara-negara lainnya seperti negara Gulf Cooperation Council (GCC) dan Malysia. Berdasarakan laporan ICD - Thomas Reutres 2017, secara total asset keuangan syariah dunia dengan total asset US $\$ 81$ miliar, meningkat dari posisi sebelumnya yang menempati posisi ke -9 pada laporan yang sama tahun sebelumnya. Membaiknya posisi Indonesia pada total asset keuangan syariah terutama didorong oleh prerkembangan pesat di sektor modal syariah khususunya perkembangan sukuk dan IKNB syariah.(LKSI, 2017)

Peran bank syariah sebagai lembaga yang bertujuan mendukung mendukung pelaksanaan pembangunan nasional, mempunyai kegiatan utama yaitu penghimpun dana dari masyarakat dan menyalurkan kepada kegiatan masyarakat. Penyaluran dana ini diwujudkan dalam bentuk pinjaman atau lebih dikenal dengan istilah pembiayaan.

Bank ketika menyalurkan kredit akan dihadapkan pada resiko. Non Performance Financing (NPF) merupakan indikator dari resiko kredit (pembiyaaan) bank. Bank dengan NPF yang tinggi cenderung lebih effisien. Bank NPF yang semakin rendah akan memiliki kemampuan menyalurkan dana kepada nasabah lainnya 
sehingga tingkat profitabilitas akan semakin tinggi. (Priantana, Riha; 2011)

Tingginya NPF menunjukan indikator gagalnya perbankan tersebut dalam mengelola dana yang disalurkan pada masyarakat untuk usaha, yang dapat mempengaruhi kinerja perbankan itu sendiri. Dilihat dari banyaknya masalah yang bisa muncul apabila nilai rasio NPF sesuai dengan ketentuan dari regulator. OJK selaku badan pemerintahan yang memiliki tugas mengatur dan mengawasi jasa keuangan akan memanggil setiap bank yang memiliki rasio NPF yang tinggi. Hal tersebut dilakukan untuk menjaga rasio NPF setiap bank tidak melebihi 5\%. (Rindang, , Syafrildha; 2019)

Salah satu indikator dalam penilaian kinerja sebuah bank syariah yang menjadi interpretasi penilaian pada aktiva produktif khususnya dalam penilaian pembiayaan bermasalah adalah Non Performance Loan (NPF). NPF atau biasa disebut sebagai pembiayaan bermasalah adalah pembiayaan yang telah disalurkan bank syariah, sedangkan nasabah tidak mampu mengembalikan angsuran pembiyaan tepat waktu sesuai dengan kesepakatan di awal perjanjian (akad) antara pihak bank syariah dengan nasabah (Ismail, 2018). Rasio NPF adalah rasio yang digunakan untuk mengukur resiko kegagalan dari pembiayaan, dimana NPF adalah rasio antara pembiayaan bermasalah (yang masuk criteria pembiayaan kurang lancer, diragukan dan macet) (Mutamimah, 2012). Terjadinya pembiayaan bermasalah atau NPF pada dasarnya dipengaruhi beberapa faktor, yaitu : (1) Faktor internal yaitu berasal dari kegiatan operasional bank termasuk kebijakan dan strategi yang ditempuh pihak bank terkait pemberian pembiayaan yang tertuang dalam laporan keuangan dan annual report bank. (2) Faktor eksternal yaitu berasal dari luar manajemen perbankan, yakni faktor yang berhubungan dengan kondisi perekonomian, kebijakan pemerintah, persaingan dan kondisi nasabah (Mahmoedin, 2004). Menurut Peraturan Bank Indonesia Nomor 6/10/PBI/2004 pembiayaan termasuk golongan perhatian khusus, kurang lancer, diragukan dan macet disebut NPF gross, sedangkan NPF netto adalah pembiayaan yang masuk pada golongan kurang lancer, diragukan dan macet. Bnak Indonesia telah menetapkan tongkat NPF gross maksimal $5 \%$ sebagai angka toleran bagi 
Kiky Asmara

kesehatan suatu bank. Semakin tinggi

NPF (diatas $5 \%$ ) makan bank tersebut dinyatakan tidak sehat karena NPF yang tinggi menyebabkan menurunnya laba yang akan diterima oleh bank.

Sepanjang tahun 2015 sampai dengan tahun 2019 perkembangan bank syariah mengalami kenaikan dan perunuran yang beragam besarnya. Namun jika dilhat besar NPF dari tahun 2015 sampai dengan 2019 memiliki nilai yang tidak melebihi apa yang sudah ditetapkan Bank Indonesai, yaitu sebesar 5\%. Pada tahun 2015 Bank Umum Syariah (BUS) dan Unit Usaha Syariah (UUS) membukukan pembiyaan yang diberikan sebesar Rp 212,96 triliun yang berarti terjadi peningkatan pembiayaan sebesar Rp 13,66 triliun atau tumbuh 6,85\% dibandingkan pembiayaan BUS dan UUS di kahir tahun 2014 yang sebesar Rp 199,3 triliun. Seiring pertumbuhan pembiyaan tersebut, rasio NPF gross BUS dan UUS pada tahun 2015 relatif sama dengan tahun 2014, namun bank telah melakukan mitigasi risiko dengan melakukan penambahan CKPN sehingga rasio NPF nett 2015 mengalami perbaikan dari sebesar 2,94\% pada tahun 2014 menjadi sebesar 2,77\%. (LKPSI, 2015).

Sementara pada tahun 2016 kualitas pembiyaan yang disalurkan BUS dan UUS yang membaik ditunjukan oleh Non Performing Financing (NPF) gross yang mengalami penurunan sebesar $0,19 \%$ sebesar 4,15\%. Sedangkan NPF di tahun 2017 juga mengalami penurunan sebesar $0,25 \%$ sebesar 3,09 \%. Penyaluran pembiayaan perbankan syariah pada tahun 2108 tumbuh 12,21\% (yoy), melambat dibandingkan tahun sebelumnya yang tumbuh sebesar 15,23\% (yoy). Perlambatan ini disebabakn oleh masih terfokusnya industri perbankan melakukan konsolidasi untuk memperbaiki kualitas pembiayaan. Hal ini ditunjukan oleh rasio non-performing financing (NPF) yang semakin membaik dengan NPF gross dan NPF net tercatat masing-masing sebesar 2,85\% dan $1,74 \%$, menurun dari tahun sebelumnya sebesar 3,87\% dan $2,13 \%$. (LKPSI , 2018).

Dalam penelitian ini faktor-faktor yang digunakan dalam penelitian ini dibatasi hanya pada beberapa variabel. Variabel yang digunakan menggambarkan kinerja perbankan dinataranya yaitu Non Performace Financing, Capital Adequacy Ratio,Financing To Deposit (FDR) , Biaya Operasional terhadap Pendapatan Operasional (BOPO). Lalu variabel yang menggambarkan kondisi

24 OECONOMICUS Journal of Economics 
makro ekonomi Indonesia di antaranya Inflasi, kurs dan GDP. Data untuk penelitian ini menggunakan data tahunanan yang dimulai dari tahun 2015 sampai dengan tahun 2019.

\section{Landasan Teori}

1. Inflasi

Inflasi secara sederhana diartikan sebagai gejala kenaikkan harga-harga barang yang bersifat umum dan berlangsung terus-menerus dalam jangka waktu tertentu (Rahardja dan Manurung : 2004). Meningkatnya harga membuat daya beli masyarakat akan berkurang dan pendapatan yang diterima dari penjualan produk dan jasa akan semakin menurun. Perusahaan dan rumah tangga yang modalnya didapat dari pembiayaan akan mengalami masalah dalam pengembalian kepada pihak bank. Hal ini akan mengakibatkan rasio atau tingkat NPF semakin tinggi bagi perbankan sendiri,begutu juga sebaliknya. (Firdaus dan Rizal : 2015).

2. Nilai Tukar (Kurs )

Nilai tukar atau kurs mata uang asing adalah harga dalam negeri dari mata uang luar negeri atau mata uang asing. Nilai tukar mata uang asing terhadap mata uang Indonesia menggambarkan kestabilan ekonomi di negara Indonesia. Penguatan nilai tukar rupiah, semakin kuat rupiah, semakin bagus perekonomian nasional negara ini. (Mutamimah,Siti : 2012). Perubahan nilai tukar rupiah memberikan pengaruh yang berbeda terhadap debitur bank. Dengan asumsi tidak dilakukan hedging untuk debitur yang bergerak dibidang eksportir, penguatan mata uang rupiah terhadap mata uang asing lain akan mengurangi pendapatannya, namun untuk ddebitur yang bergerak dalam bidang importer hal sebaliknya yang akan terjadi yaitu penguatan mata uang rupiah akan menambah pendapatannya. Perbedaan tersebut menyebabkan pengaruh perubahan nilai tukar terhadap kinerja debitur akan berbeda-beda sehingga pengaruhnya terhadap NPF juga akan berbeda. Dengan demikian dapat disimpulkan apabila terjadi peningkatan terhadap angka nilai tukar terhadap dolar amerika 
Kiky Asmara

maka nilai tukar atau kurs rupiah terhadap dolar mengalami penurunan dan ini akan menyebabkan bank menanggung resiko pembiayaan lebih tinggi. (Mia ,Syaichu : 2012).

3. GDP

Gross Domestic Product (GDP) digunakan untuk mengukur semua barang dan jasa yang dihasilkan dalam perekonomian suatu negara dalam periode tertentu. Hubungan GDP dengan kredit bermasalah, dalam kondisi resesi (terlihat dari penurunan GDP) dimana terjadi penurunan penjualan dan pendapatan perusahaan, maka akan mempengaruhi kemampuan perusahaan dalam mengembalikan pinjamnannya. Hal ini akan menyebabkan bertambahnya outstanding kredit non lancar (Rahmawulan, 2008).

4. CAR

Capital Adequacy Ratio (CAR) adalah rasio perbandingan jumlah baik modal inti maupun modal pelengkap terhadap aktiva tertimbanng menurut risiko (ATMR). Kecukupan modal merupakan faktor yang sangat penting bagi bank dalam rangka menampung resiko kerugian atas tidak dibayarkannya kembali pembiayaan yang diberikan kepada nasabahnya. (Sri Wahyuni : 2104). Ketika CAR pada Bank Umum Syariah meningkat, maka Bank Umum Syariah akan merasa aman untuk menyalurkan pembiayaannya. Namun hal ini akan berakibat Bank Umum Syariah akan merasa lebih longgar dalam ketentuan penyaluran pembiayaannya . Jika kondisi ini terjadi, maka resiko pembiayaan yang diberikan kepada nasabah yang tidak layak akan semakn besar, sehingga jika tidak tertagih, ,maka akan meningktkan NPF (Mardiana,2013).

5. FDR

Financing to Deposite Ratio (FDR) adalah perbandingan antara pembiayaan yang diberikan oleh bank dengan dana pihak ketiga yang berhasil dikerahkan oleh bank. Sehingga semakin tinggi FDR suatu bank, berarti dana pihak ketiga terserap semua ke pembiyaan. Pembiyaan yang tinggi lambat laun dapat meneurunkan kualitas dari pembiayaan tersebut. Dari segi kuantitas semakin banyak pembiyaan yang dikeluarkan maka, resiko pembiayaan bermaslah / NPF menjadi lebih besar. Jadi 
semakin tinggi FDR semakin tinggi pula NPF. Demikian pula sebaliknya.(Haifa,Dedi :21005). FDR maksimal yang diperkenankan oleh Bank Indonesia adalah sebesar $110 \%$. Semakin tinggi penyaluran dana yang disalurkan melalui pembiayaan, maka kemungkinan resiko pembiayaan bermasalah akan meningkat, sehingga NPF juga akan meningkat. (Suhartatik,Kusumaningtias : 2013).

6. BOPO

Biaya Operasional terhadap Pendapatan Operasional (BOPO) adalah penghimpunan dana dan penyaluran dana. Rasio BOPO ini berkaitan erat dengan kegiatan operasional bank syariah. Biaya operasional bank syariah yang terlalu tinggi tidak akan mendatangkan keuntungan bagi bank syariah. Pendapatan bank syariah yang tinggi dengan biaya operasional yang rendah dapat menekan rasio BOPO sehingga bank syariah berada pada posisi sehat, yang artinya kecenderungan terjadinya pembiayaan bermasalah pun akan rendah dapat menekan rasio BOPO sehingga bank syariah berada pada posisi sehat, yang artinya kecenderungan terjadinya pembiyaan bermasalah pun akan rendah.(Mia, Syaichu : 2016)

\section{Metode Penelitian}

Penelitian ini mengunakan metode regresi berganda, yaitu suatu metode yang gunakan untuk mengetahui faktor mana yang dianggap paling mempengaruhi dan memiliki pengaruh paling besar dari beberapa faktor yang digunakan dalamm penelitian ini.

\section{a. Hipotesis penelitian}

1). Ho : Tidak terdapat pengaruh terhadap faktor eksternal dan faktor internal terhadap Non Performance Finance

(NPF) Perbankan Syariah di Indonesia.

2). Ha : Terdapat pengaruh terhadap faktor eksternal dan faktor internal terhadap Non Performance Finance (NPF) Perbankan Syariah di Indonesia. 


\section{b. Kerangka Penelitian}

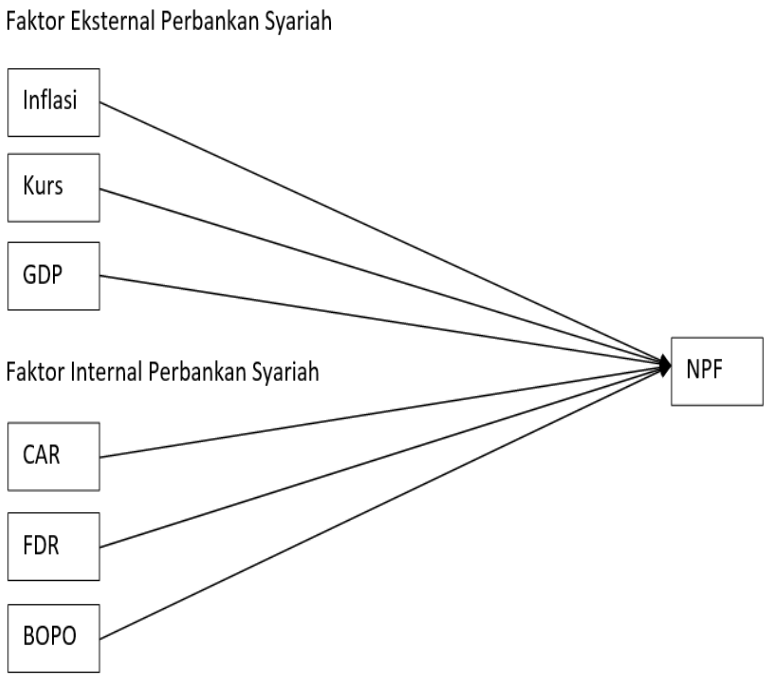

\section{c. Jenis Penelitian}

Penelitian ini menggunakan metode deskriktif yang menggambarkan fenomena yang ada. Sumber data yang digunakan adalah data sekunder,sedangkan teknik pengumpulan datanya adalah melalui pengumpulan dan pencatatan dari statistk perbankan syariah dan laporan statistik Indonesia dari tahun 2015 sampai tahun 2019 secara bulanan.

\section{Pembahasan}

Model ekonometrika yang digunakan untuk melihat ada tidaknya pengaruh faktor internal (inflasi,kurs,GDP) dan faktor eksternal (CAR,FDR,BOPO) terhadap Non Performing Financing (NPF) Perbankan Syariah. Model ekonometrika yang digunakan yaitu model persamaan

$$
\begin{aligned}
& \begin{aligned}
& \mathrm{NPF}= \beta 0+\beta 1 \mathrm{INF}+\beta 2 \mathrm{KURS}+\beta 3 \mathrm{GDP}+\beta 4 \mathrm{CAR}+\beta 5 \mathrm{FDR}+ \\
& \beta 6 \mathrm{BOPO}+\mathrm{e} . \\
& \text { atau } \mathrm{Y}= \beta 0+\beta 1 \times 1+\beta 2 \times 2+\beta 3 \times 3+\beta 4 \times 4+\beta 5 \times 5+\beta 6 \times 6+\mathrm{e} . \\
& \text { Sehingga dari hasil olah data dapat dituliskan persamaan sesuai }
\end{aligned} \\
& \text { OECONOMICUS Journal of Economics }
\end{aligned}
$$


dengan variabel penelitian yaitu :

$$
\begin{aligned}
\mathrm{Y}= & 10,599+0,334 \times 1+0,000 \times 2-5,9 \mathrm{E}-007 \times 3+0,045 \times 4-0,022 \times 5+ \\
& 0,164 \times 6+\mathrm{e}
\end{aligned}
$$

Untuk pengujian koefisien dterminasi dari hasil olah didapatkan nilai R2 sebesar 0,929 atau 92,9\% artinya dari seluruh pengamatan menunjukan bahwa semua variabel bebasnya dapat menjelaskan variabel terikatnya sebesar 0,929 sedangkan sisanya 0,071 atau 7,1 \% dipengaruhi oleh faktor lain. Nilai R2 yang hamper mendekati 1 atau $100 \%$ dapat diartikan bahwa hubungan antara variabel bebas terdapat variabel terikat memiliki hubungan yang kuat. Sedangkan pengujian secara simultan dapat disimpulkan bahwa seluruh variabel bebasnya Inflasi (x1), Kurs (x2), GDP (x3), CAR (x4), FDR (x5) dan BOPO (x6) berpengaruh secara simultan terhadap Non Performance Financing (NPF). Hal ini dapat dilihat dari besarnya nilai $F$ hitung sebesar 9,507 > F tabel sebesar 3,49.

Pengujian yang terakhir ada pengujian secara parsial atau biasa disebut uji t. Uji ini merupakan pengujian yang dilakukan untuk mengetahui ada tidaknya pengaruh secara parsial (indivudu). Dari hasil analisis data bisa di ambil kesimpulan untuk variabel :

\section{Pengaruh Inflasi terhadap Non Performing Financing (NPF)}

Memiliki nilai t hitung sebesar 2,594 dengan nilai probabilitas sebesar 0,029 maka Ho ditolak dan Ha diterima, dengan demikian dapat disimpulkan bahwa variabel inflasi (x1) secara parsial berpengaruh positif terhadap Non Performing Financing ( $\mathrm{Y}$ ). Dengan nilai r2 sebesar 0,654 atau 65,4\%. Dapat diartikan bahwa variabel inflasi (x1) dapat menjelaskan variabel terikatnya sebesar 0,654 sedangkan sisanya 0,346 atau $34,6 \%$ dipengaruhi oleh faktor lain.

\section{Pengaruh Kurs terhadap Non Performing Financing (NPF)}

Variabel kurs memiliki nilai thitung sebesar 0,462 dengan nilai probabilitas sebesar 0,655 maka Ho diterima dan Ha ditolak, dengan demikian dapat disimpulkan bahwa variabel Kurs (x2) secara parsial tidak berpengaruh terhadap Non Performing Financing $(\mathrm{Y})$ Dengan nilai r2 sebesar 0,154 atau 15,4\%. Dapat diartikan bahwa variabel kurs (x2) dapat menjelaskan variabel terikatnya hanya 
Kiky Asmara

sebesar 0,154 sedangkan sisanya 0,846 atau 84,6\% dipengaruhi oleh faktor lain.

\section{Pengaruh GDP terhadap Non Performing Financing (NPF)}

Memiliki nilai t hitung sebesar -0,523 dengan nilai probabilitas sebesar 0,0,613 maka Ho diterima dan Ha ditolak, dengan demikian dapat disimpulkan bahwa variabel GDP (x3) secara parsial tidak berpengaruh terhadap Non Performing Financing $(Y)$. Dengan nilai r2 sebesar 0,172 atau 17,2 \%. Dapat diartikan bahwa variabel GDP (x3) dapat menjelaskan variabel terikatnya sebesar 0,172 sedangkan sisanya 0,828 atau $82,8 \%$ dipengaruhi oleh faktor lain. Sehingga dapat dikatakan bahwa keeratan hubungan antara variabel GDP dengan NPF kurang kuat.

\section{Pengaruh CAR terhadap Non Performing Financing (NPF)}

Memiliki nilai t hitung sebesar 0,323 dengan nilai probabilitas sebesar 0,754 maka Ho diterima dan Ha ditolak, dengan demikian dapat disimpulkan bahwa variabel CAR (x4) secara parsial tidak berpengaruh terhadap Non Performing Financing $(Y)$. Dengan nilai r2 sebesar 0,107 atau 10,7 \%. Dapat diartikan bahwa variabel CAR (x4) dapat menjelaskan variabel terikatnya sebesar 0,107 sedangkan sisanya 0,893 atau 89,3 \% dipengaruhi oleh faktor lain. Sehingga dapat dikatakan bahwa keeratan hubungan antara variabel CAR dengan NPF kurang kuat.

\section{Pengaruh FDR terhadap Non Performing Financing (NPF)}

Memiliki nilai $t$ hitung sebesar $-0,680$ dengan nilai probabilitas sebesar 0,514 maka Ho diterima dan Ha ditolak, dengan demikian dapat disimpulkan bahwa variabel FDR (x5) secara parsial tidak berpengaruh terhadap Non Performing Financing $(Y)$. Dengan nilai r2 sebesar 0,221 atau 22,1\%. Dapat diartikan bahwa variabel FDR (x5) dapat menjelaskan variabel terikatnya sebesar 0,221 sedangkan sisanya 0,779 atau $77,9 \%$ dipengaruhi oleh faktor lain.

\section{Pengaruh BOPO terhadap Non Performing Financing (NPF)}

Memiliki nilai thitung sebesar 0,4,141 dengan nilai probabilitas sebesar 0,003 maka Ho ditolak dan Ha diterima, dengan demikian dapat disimpulkan bahwa variabel BOPO (x6) secara parsial berpengaruh terhadap Non Performing Financing $(Y)$. Dengan nilai 
r2 sebesar 0,810 atau $81,0 \%$. Dapat diartikan bahwa variabel BOPO (x6) dapat menjelaskan variabel terikatnya sebesar 0,810 sedangkan sisanya 0,19 atau $19 \%$ dipengaruhi oleh faktor lain. 


\section{Penutup}

Hasil analisa data dapat memberikan kesimpulan bahwa variabel yang memiliki pengaruhterhadap NPF dari faktor eksternal yaitu inflasi sedangkan dari faktor internal adalah BOPO. Sedangkan variabel alin baik dari faktor eksternal dan internal semuanya tidak memilki pengaruh terhadap NPF . Karena adanya keterbatasan waktu dalam penelitian ini maka peneliti selanjutnya dapat lebih memperpanjang waktu penelitian serta lebih banyak lagi variabelvariabel yang mungkin mempengaruhi Non Performaing Financing (NPF).

\section{Daftar Referensi}

Prinatana, Riha Dedi dan Zulfia, 2011. Pengaruh Rasio Kecukupan Modal, Non Performing Loan dan Tingkat Likuiditas terhadap Profitabilitas Perbanakan yang Terdaftar di Bursa Efek Indonesia. Jurnal Akuntansi dan Keuangan .Vol.1 No.1.

Rindang Nur Isnaini Nugrohowati, Syafrildha Bimo, 2019. Analisis Pengaruh Faktor Internal Bank dan Eksternal Terhadap Non-Performing Financing (NPF) pada Bank Perkreditan Rakyat Syariah di Indonesia. Jurnal Ekonomi dan Keuangan Islam, Vol.5 No.1.

Rahardja, Pratama dan Mandala Manurung, 2004. Pengantar Makroekonomi. Jakarta : LPFE-UI.

Firdaus,Rizal Nur, 2015. Pengaruh Faktor Internal dan Eksternal yang Mempengaruhi Pembiayaan Bermasalah pada Bank Umum Syariah di Indonesia, FakultasEkonomi dan Bisnis Universitas Brawijaya.

Ismail, 2018. Manajemen Perbankan : Dari Teori Menuju Aplikasi. Jakarta : Kecana. 
Mahmoedin, 2010. Melacak Kredit Bermasalah. Jakarata : Pustaka Sinar Harapan.

Mutamimah, Siti Nur , 2012, Analisis Eksternal Dan Internal Dalam Menetukan Non Performance Financing Bank Umum Syariah Di Indonesia, Jurnal Bisnis dan Ekonomi . Vol 19 No.1.

Mia Maraya Aulia, Syaichu , 2016, Analisis Pengaruh Faktor Internal Dan Faktor Eksternal Terhadap Tingkat Pembiyaan Bermasalah Pada Bank Umum Syariah Di Indonesia Periode Tahun 2010-2014, Diponegoro Journal Of Management, Vol 5. No 3.

Rahmawulan, Yunis, 2008. Bank dan Lemabaga Keuangan Lainnya, Edisi Keempat, PT. Garfindo Persada, Jakarta.

Suhartatik Nur dan Kusumaningtias, 2013. Determinan Financing to Deposit Ratio Perbankan Syariah di Indonesia, Jurnal Manajemen, Fakultas Ekonomi Universitas Negeri Surabaya

Sri Wahyuni, 2014, Faktor-Faktor Yang Mempengaruhi Non Performing Financing (NPF) Pada Bank Umum Syariah Di Indonesia, Jurnal TEKUN, Vol 5 No.2

Haifa, Dedi Wibowo, 2015, Pengaruh Faktor Internal Bank Dan Makro Ekonomi Terhadap Non Performing Financing Perbankan Syariah Di Indonesia : Periode 2010:01 2014:04, Jurnal Nisbah Vol.1 No.2 
Kiki Asmara

34 OECONOMICUS Journal of Economics 